\title{
Article \\ Comparison of the Effect of Enhancing Dry Fermented Sausages with Salvia hispanica and Nigella sativa Seed on Selected Physicochemical Properties Related to Food Safety during Processing
}

\author{
Paula Borrajo $^{1}\left(\mathbb{D}\right.$, Małgorzata Karwowska ${ }^{2, * \mathbb{D}}$, Dariusz M. Stasiak ${ }^{2} \mathbb{D}$, Jose M. Lorenzo ${ }^{1,3} \mathbb{D}$, Marlena Żyśko $^{2}$ \\ and Elżbieta Solska ${ }^{2}$ \\ 1 Centro Tecnológico de la Carne de Galicia, Rúa Galicia N 4, Parque Tecnológico de Galicia, San Cibrao \\ das Viñas, 32900 Ourense, Spain; paulaborrajo@ceteca.net (P.B.); jmlorenzo@ceteca.net (J.M.L.) \\ 2 Department of Meat Technology and Food Quality, University of Life Sciences in Lublin, ul. Skromna 8, \\ 20-704 Lublin, Poland; dariusz.stasiak@up.lublin.pl (D.M.S.); marlenazysko@onet.eu (M.Ż.); \\ elzbieta.solska@up.lublin.pl (E.S.) \\ 3 Área de Tecnología de los Alimentos, Facultad de Ciencias de Ourense, Universidad de Vigo, \\ 32004 Ourense, Spain \\ * Correspondence: malgorzata.karwowska@up.lublin.pl
}

\section{check for} updates

Citation: Borrajo, P.; Karwowska, M.; Stasiak, D.M.; Lorenzo, J.M.; Żyśko, M.; Solska, E. Comparison of the Effect of Enhancing Dry Fermented Sausages with Salvia hispanica and Nigella sativa Seed on Selected Physicochemical Properties Related to Food Safety during Processing. Appl. Sci. 2021, 11, 9181. https:// doi.org/10.3390/app11199181

Academic Editor: Wojciech Kolanowski

Received: 12 August 2021

Accepted: 24 September 2021

Published: 2 October 2021

Publisher's Note: MDPI stays neutral with regard to jurisdictional claims in published maps and institutional affiliations.

Copyright: (c) 2021 by the authors. Licensee MDPI, Basel, Switzerland. This article is an open access article distributed under the terms and conditions of the Creative Commons Attribution (CC BY) license (https:/ / creativecommons.org/licenses/by/ $4.0 /)$.

\begin{abstract}
The aim of the study is to compare the effects of Salvia hispanica (Chia) seed and Nigella sativa (Black Cumin) seed in traditionally produced dry fermented sausages with reduced nitrites on the changes in physicochemical parameters (water content, $\mathrm{pH}$, and water activity), thioarbituric acid reactive substances (TBARS), color parameters, the content of nitrosopigments, and microbial counts throughout the production process. At the end of the processing, the content of biogenic amines was also determined. Five samples were analyzed during the 30-day production process: the control sample, samples with $1 \%$ and $2 \%$ additions of chia seed, and samples with $1 \%$ and $2 \%$ additions of black cumin seed. It was indicated that the addition of chia or black cumin did not exert any effect on water content or water activity changes in fermented sausages. At the end of production, the samples were characterized by low water activity, in the range of $0.798-0.813$. The sausages with chia seeds were characterized by the lowest $\mathrm{pH}$ due to the highest proliferation of lactic acid bacteria. TBARS values did not alter in both control and black cumin sausages throughout the experiment. Microbiological analysis showed that the addition of chia or black cumin seed enhances the proliferation of the lactic acid bacteria and caused a reduction in the number of Enterobacteriaceae in comparison to the control.
\end{abstract}

Keywords: chia seeds; black cumin seeds; fermented sausage; biogenic amines; nitrosylmyoglobin; lactic acid bacteria

\section{Introduction}

Meat consumption has been increased considerably during the last few years because the world's population is continuously growing, as well as due to rapid industrialization. The global meat production predicted in the coming years will rise drastically, and therefore the meat industry should meet the demand for these needs. This sector is considered one of the most important worldwide, and its production in 2019 was around 337 million tonnes. Europe represents about one-fifth of the world's production, providing 64 million tonnes, of which 5 million tonnes correspond to Poland [1]. Meat constitutes a significant part of the human diet due to its nutritional value. Although the meat consumption has a negative impact on the environment and is classified as a probable human carcinogen [2], it is an exceptional source of valuable nutrients, including highly bioavailable essential amino acids, vitamins, and minerals [3]. However, its consumption is subjected to consumer 
concerns, lifestyles, and preferences, as well as cultural and geographical factors. In this evolution, the demand to extend meat shelf-life is increasing since it is related to safety and quality assurance. The fermentation process is one of the techniques traditionally employed to extend the shelf life of meat, and it is catalyzed by the action of both endogenous microbial enzymes and muscle enzymes [4,5]. The formation of end products originated by the changes of lipids, proteins, and fermentable sugars (i.e., glucose or fructose, added by the manufacturer) have a great impact on the quality characteristics of the product [6]. Fermented meats are included in the human diet as important constituents due to their nutritional value, shelf life, and special sensorial characteristics. Dry fermented sausages are traditional ready-to-eat meat products widely consumed in Europe [7-9]. The characteristic flavor and taste that make them unique are considered the most relevant attributes that strongly influence consumer acceptability and preference $[10,11]$. Lactic acid bacteria (LAB) are the most active microorganisms responsible for acidification during fermentation, resulting in the development of the desirable flavor, taste, color, and texture of the products. They produce lactic acid and bacteriocins that prevent the growth of spoilage and pathogenic microorganisms. Therefore, there is an enhancement in the stability, safety, and shelf-life of the sausages [6,11-13].

The main biochemical changes originating during the ripening of the dry-fermented sausages are lipolysis and proteolysis. During the lipid oxidation, the intramuscular phospholipids undergo significant changes generating polyunsaturated fatty acids such as linoleic, linolenic, and arachidonic acids [14]. The muscle peptidases (principally cathepsins) initiate the breakdown of the proteins along the process, whereas microbial enzymes exert their function in the final stages of aging [6,8]. Consequently, a substantial amount of low-molecular-weight compounds such as peptides and amino acids is released. The compounds produced by the lipolysis and proteolysis are intimately related to the organoleptic properties (aroma, taste, and flavor) and other diverse functionalities of the final dryfermented product [13].

The growing interest in promoting and enhancing human health has increased the efforts of the food industry to search for functional ingredients [15]. Plants generally contain alkaloids, flavonoids, polyphenols, saponins, and tannins that influence animals due to their different functions and benefits [16]. The incorporation of these natural origin ingredients into meat products has gained attention during the last years since they are a source of bioactive compounds [17]. Another strategy to improve the nutritional value of meat products is to eliminate or reduce synthetic additives such as nitrogen compounds. This is related to their harmfulness. Breda et al. [18] indicated the carcinogenic effect of nitrite, pointing to its reactions with $\mathrm{N}$-nitroso compound precursors in the gastrointestinal tract, thereby subsequently forming potentially carcinogenic compounds.

Nigella sativa, commonly known as black cumin, has been widely employed for centuries for culinary and pharmaceutical purposes throughout the world $[19,20]$. Seeds are highly valuable due to their content of bioactive compounds with antimicrobial, antioxidant, antifungal, and anti-inflammatory properties [19,21]. The most active constituent present in seeds is thymoquinone. Moreover, they also contain other active compounds such as carvacrol, p-cymene, 4-terpineol, trans-anethol, dithymoquinone, and thymohydroquinone, among others. In addition, they present amino acids, fats, reducing sugars, sterols, quinones, and essential minerals including calcium, copper, iron, and phosphorus and vitamins such as folic acid, niacin, pyridoxine, and thiamin [17,21-23].

Chia (Salvia hispanica) seeds have been popularly used as ingredients in healthy foods due to their high levels of dietary fiber and low carbohydrates [24,25]. These pseudocereals are characterized by their high concentration of essential polyunsaturated fatty acids such as $\alpha$-linolenic acid $(\omega-3)$ and linoleic acid $(\omega-6)$. They contain a great number of antioxidants with strong activity such as flavonoids (myricetin, kaempferol, and quercetin), tocopherols, polyphenols, caffeic, cinnamic, and chlorogenic acids [26-29]. The functional seeds mentioned above offer benefits beyond their nutritional value as they exert beneficial properties for human health. They are suitable candidates as food ingredients in meat 
products. There are some studies about the addition of chia seeds into meat products such as camel burgers [29] and frankfurters [25].

Therefore, the objective of the study is to compare the effects of Salvia hispanica seed and Nigella sativa seed in traditionally produced dry fermented sausages with reduced nitrites on the changes in physicochemical parameters (water content, $\mathrm{pH}$, and water activity), color parameters, the content of nitrosopigments, and microbial counts throughout the production process. Additionally, at the end of the processing, the content of biogenic amines was determined.

\section{Material and Methods}

\subsection{The Experimental Material Preparation}

The study was performed in the Department of Meat Technology and Food Quality (University of Life Sciences in Lublin, Poland) in semi-technical conditions. Five different sample groups of dry fermented sausages were produced with reduced sodium nitrite addition $\left(50 \mathrm{mg} \mathrm{kg}^{-1}\right)$ in relation to the permitted amount in accordance with the Commission Regulation (EU) No. 1129/2011 [30]. The amount of nitrite permitted for use in cured meat products is currently $150 \mathrm{mg} \mathrm{kg}^{-1}$. Products were made with two replications. Dry fermented meat products were made using ham muscles from Polish large white purebred fatteners obtained from a local slaughterhouse at $48 \mathrm{~h}$ postmortem. The raw material was delivered in cooling conditions to the laboratory. Then, the meat was minced through a $10 \mathrm{~mm}$ grinding plate using the universal machine type KU2-3EK (Mesko-AGD, SkarżyskoKamienna, Poland). To each formulation, $0.6 \%$ of glucose and $2.8 \%$ of curing mixture (Sea salt + Sodium nitrite) were added. The composition of the mixture and the amount of its application ensured the presence of sodium nitrite in the stuffing in the amount of $50 \mathrm{mg} \mathrm{kg}^{-1}$. Grounded Salvia hispanica (Chia) seed and Nigella sativa (Black Cumin) seed were added into some samples (SCh1, SCh2, SBC1, and SBC2) in the amounts of $1 \%$ and $2 \%$. The seeds were ground just before use using a knife mill (Bosch TSM6A017C) for particles less than $0.3 \mathrm{~mm}$ in diameter. Salvia hispanica seed and Nigella sativa seed were purchased in the local market. The groups of dry fermented sausages were presented in Figure 1. After mixing all ingredients using the universal machine type KU2-3EK (Mesko-AGD, Skarżysko-Kamienna, Poland) with an attached R4 type mixer (100 rpm, $3 \mathrm{~min}$ ), the raw batters were stuffed into fibrous casings (ø $65 \mathrm{~mm}$; Viskase, Chicago, USA) using a vertical manual sausage stuffer. Sausages of about $400 \mathrm{~g}$ were prepared. In the next step, sausage samples have been placed in fermentation chambers (ITALFROST-DE RIGO-GS, Pszczyna, Poland) for 30 days under controlled humidity and temperature conditions. Production conditions are given in Figure 1. Samples of each batch were taken at 1, 10, 20, and 30 days of the production.

The physicochemical parameters (water content, $\mathrm{pH}$, and water activity), instrumental color, the content of nitrosopigments, and microbial counts (content of LAB and Enterobacteriaceae) were measured in stuffing (Day 1), 10, 20, and 30 days of the production. At 30 days, the content of biogenic amines and the content of Listeria monocytogenes were additionally made. The treatments were replicated twice by producing two different batches. Each sample was analyzed in triplicate. 


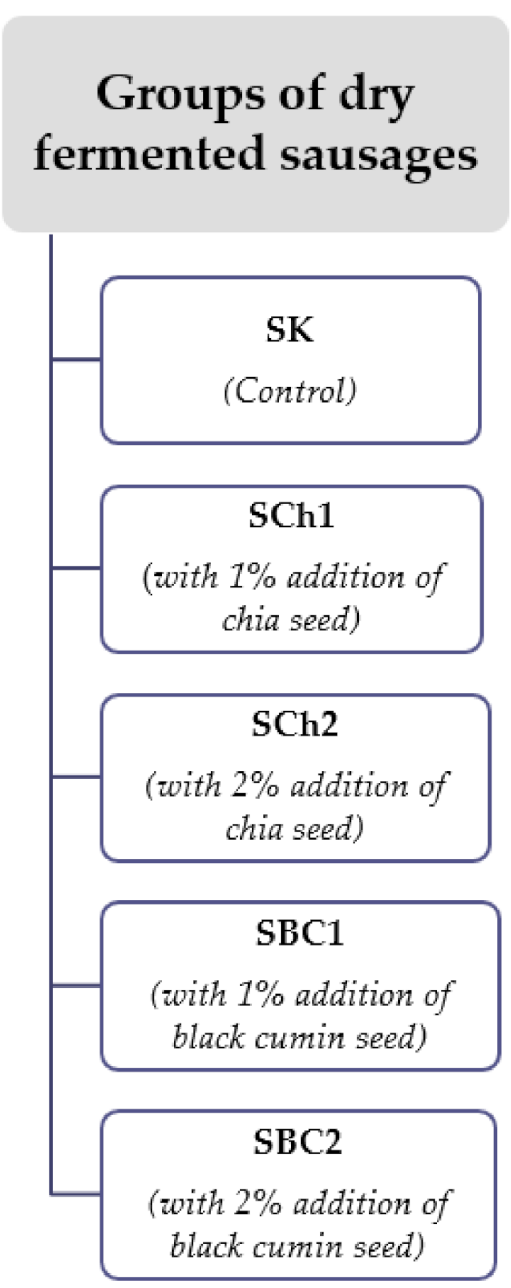

\section{Production conditions}

(in fermentation chamber under controlled humidity $(\mathrm{RH})$ and temperature (T))

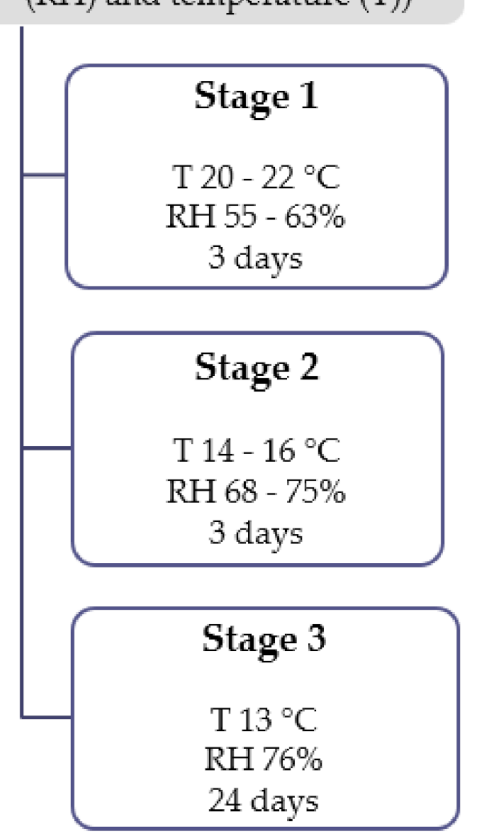

Figure 1. The groups of dry fermented sausages and production conditions.

\subsection{The Physicochemical Parameters (WC-Water Content, $p H$, and Water Activity)}

The water content (WC) was determined according to PN ISO 1442:2000 [31]. A digital pH meter CPC-501 (Elmetron, Zabrze, Poland) equipped with a temperature sensor and $\mathrm{pH}$ electrode (ERH-111, Hydromet, Gliwice, Poland) was used to measure $\mathrm{pH}$ of the samples. The water activity $\left(\mathrm{a}_{\mathrm{w}}\right)$ was measured using a water activity analyzer (Novasina AG, Lachen, Switzerland), which gives temperature-controlled measurements. Measurements were made at a temperature of $20{ }^{\circ} \mathrm{C}$. Analyzer had been calibrated with Novasina SAL-T humidity standards (33\%, 75\%, 84\%, and $90 \%$ relative humidity).

\subsection{Lipid Oxidation Analyzes}

Lipid oxidation in the sausages was assessed by measuring the amount of thiobarbituric acid reactive substances (TBARS) according to the procedure described by Pikul et al. [32]. The values were expressed as $\mathrm{mg}$ of malondialdehyde (MDA) per kilogram of sample.

\subsection{Instrumental Color Measurement and Nitrosylmyoglobin Content}

Color parameters were determined on the cross-section just after the sample (at least $20 \mathrm{~mm}$ thick) was cut [33]. Color parameters $\left(\mathrm{L}^{*}, \mathrm{a}^{*}, \mathrm{~b}^{*}\right)$ were measured using an X-Rite 8200 colorimeter (X-Rite, Inc., Michigan, USA). Before use, the colorimeter was calibrated using the black glasses and white tiles provided. Samples were analyzed directly over the $12 \mathrm{~mm}$ aperture, with D65 illumination configurations and 10 viewing angles. The color difference $(\Delta \mathrm{E})$ between control and test samples during storage was calculated according to AMSA [33] using the following formula: 


$$
\Delta E=\sqrt{(\Delta L)^{2}+(\Delta a)^{2}+(\Delta b)^{2}}
$$

In the interpretation of the results, it was assumed that when $0<\Delta \mathrm{E}<1$, the observer does not notice the difference; when $1<\Delta \mathrm{E}<2$, only an experienced observer may notice the difference; when $2<\Delta \mathrm{E}<3.5$, an unexperienced observer also notices the difference; when $3.5<\Delta \mathrm{E}<5$, a clear difference in color is noticed; and when $5<\Delta \mathrm{E}$, an observer notices two different colors [34].

The nitrosylmyoglobin content were determined according to the procedure proposed by Hornsey [35]. The amount of nitrosylmyoglobin was calculated according to Hornsey [35] and expressed in $\mathrm{mg} \mathrm{kg}^{-1}$.

\subsection{Microbiological Analyzes}

The microbiological analyses included the number of lactic acid bacteria (LAB) and the number of Enterobacteriaceae (EB) bacteria. They were made using the TEMPO ${ }^{\circledR}$ LAB automated microbial counting system (Biomerieux, TEMPO ${ }^{\circledR}$ System, Marcy l'Etoile, France). For microbiological determinations, the original TEMPO ${ }^{\circledR}$ tests were used to determine the number of lactic acid bacteria (TEMPO LAB) and the number of Enterobacteriaceae (TEMPO EB) in food products. The incubation conditions used for the TEMPO LAB and TEMPO EB tests include: incubation time (h) $-40-48$ and 22-27; temperature of incubation $\left({ }^{\circ} \mathrm{C}\right)-37$ and 35 , respectively. The results are expressed as a logarithm colony-forming unit per gram of products $\left(\log \mathrm{CFU} \mathrm{g}{ }^{-1}\right)$. L. monocytogenes detection was carried out at Agrolab Polska Sp. z o. o. (Dęblin, Poland) according to ISO:11290-2:1998 [36].

\subsection{Biogenic Amines (BAs) Determination}

Biogenic amines (BAs) were determined in dry fermented sausages samples after extraction using $10 \%$ trichloroacetic acid (TCA). The analysis of BAs was performed using an AAA 500 amino acid analyzer (Ingos, Praha, Czech Republic), equipped with an Ostion LG AAA8 ion-exchange column $(3.6 \times 100 \mu \mathrm{m}, 8 \mu \mathrm{m})$. Standards of BAs with a purity of $99 \%$ were obtained from Sigma-Aldrich (St. Louis, MO, USA). Solutions of BAs were prepared with a dilution buffer composed of $1.5 \mathrm{mM} \mathrm{NaN} 3,197 \mathrm{mM} \mathrm{NaCl}$, and $73 \mathrm{mM}$ citric acid in Milli-Q water. The system consisted of a filling chromatographic column and steel pre-column, two chromatographic pumps for transport of elution buffers and derivatization reagent, a cooled carousel for Eppendorf tubes, a dosing valve, a heat reactor, a Vis detector, and a cooled chamber for derivatization reagent. The volume of the injected sample was $100 \mu \mathrm{L}$. The reactor temperature was set to $120^{\circ} \mathrm{C}$. The content of the BA (tyramine, putrescine, cadaverine, spermidine, agmatine, and spermine) was determined with a reference to the amine standards, which were supplied by Ingos, Czech Republic. The BA concentrations were reported as $\mathrm{mg} \mathrm{g}^{-1}$ of product.

\subsection{Statistical Analysis}

The collected data were analyzed using Statistica version 13.3 software (Dell Inc., Round Rock, TX, USA). The results were expressed as mean \pm standard deviations. The data normality and homogeneity were analyzed using a Shapiro-Wilk test and a Levene's test. Effects between categorical factors (day and type of sausage) and variables between subgroups were analyzed using factorial ANOVA. The homogeneous groups are identified using the post hoc HSD Tukey's test. Additional information was obtained using the principal component analysis (PCA) method and the dendrite method for cluster analysis. The dataset was treated by Ward's method of linkage with squared Euclidean distance as a measure of similarity for multivariate analysis.

\section{Results}

\subsection{The Results of Physicochemical Parameters (Water Content, $p H$, and Water Activity)}

During the dry-curing process, a progressive diminution of water content was observed due to the water losses in all sausages (Table 1). No significant differences were 
observed among batches, so the gradual losses were similar in all cases. On the last day of the study, the sausages lost half of their water content, from an average of $66 \%$ on Day 1 to $33 \%$ on Day 30. On the first day of analysis, all batches registered the highest $\mathrm{pH}$ values except the control, where the highest was at Day 30 (5.92) (Table 1). Moreover, the $\mathrm{pH}$ did not vary among the samples on the first day (5.69-5.78). The $\mathrm{pH}$ decreased up to 20 days of ripening, reaching the lowest values on the same day. However, on Day 30, there was a slight increase. It should be noted that the control sausages showed the highest $\mathrm{pH}$ on the rest of the sampling days (5.56, 5.27, and 5.92 at 10, 20, and 30 days, respectively). Conversely, the sausages with chia seeds were characterized by the lowest $\mathrm{pH}$.

Table 1. The evolution of physicochemical parameters during the manufacturing process of dry fermented sausages.

\begin{tabular}{|c|c|c|c|c|c|}
\hline \multirow{2}{*}{ Parameter } & \multirow{2}{*}{ Treatment } & \multicolumn{4}{|c|}{ Processing Day } \\
\hline & & Day 1 & Day 10 & Day 20 & Day 30 \\
\hline \multirow{5}{*}{ Water content (\%) } & SK & $67.09 \pm 0.70 \mathrm{aC}$ & $49.66 \pm 2.34^{\mathrm{aB}}$ & $36.28 \pm 3.02^{\mathrm{aA}}$ & $32.87 \pm 1.73^{\mathrm{aA}}$ \\
\hline & SCH1 & $66.33 \pm 1.37^{\mathrm{aC}}$ & $50.48 \pm 2.22^{a B}$ & $35.72 \pm 1.39^{\mathrm{aA}}$ & $33.44 \pm 1.11^{\mathrm{aA}}$ \\
\hline & SCH2 & $64.41 \pm 1.04^{\mathrm{aC}}$ & $48.65 \pm 1.50^{a B}$ & $34.21 \pm 0.33^{\mathrm{aA}}$ & $32.93 \pm 1.55^{\mathrm{aA}}$ \\
\hline & SBC1 & $65.37 \pm 0.84^{\mathrm{aC}}$ & $50.06 \pm 1.40^{\mathrm{aB}}$ & $36.61 \pm 0.85^{\mathrm{aA}}$ & $34.33 \pm 0.96^{\mathrm{aA}}$ \\
\hline & SBC2 & $65.69 \pm 1.86^{\mathrm{aC}}$ & $50.01 \pm 0.72^{a B}$ & $34.75 \pm 0.35^{\mathrm{aA}}$ & $32.36 \pm 1.12^{\mathrm{aA}}$ \\
\hline \multirow{5}{*}{$\mathrm{pH}$} & SK & $5.75 \pm 0.03^{\mathrm{aC}}$ & $5.56 \pm 0.03^{\mathrm{dB}}$ & $5.27 \pm 0.08^{\mathrm{dA}}$ & $5.92 \pm 0.04^{\mathrm{cD}}$ \\
\hline & $\mathrm{SCH} 1$ & $5.78 \pm 0.01^{\mathrm{aD}}$ & $4.92 \pm 0.02^{\mathrm{bB}}$ & $4.72 \pm 0.03^{\mathrm{abA}}$ & $5.29 \pm 0.03^{\mathrm{aC}}$ \\
\hline & $\mathrm{SCH} 2$ & $5.69 \pm 0.01^{\mathrm{aD}}$ & $4.81 \pm 0.05^{\mathrm{aB}}$ & $4.62 \pm 0.01^{\mathrm{aA}}$ & $5.21 \pm 0.02^{\mathrm{aC}}$ \\
\hline & SBC1 & $5.72 \pm 0.05^{\mathrm{aD}}$ & $5.04 \pm 0.02 \mathrm{cB}$ & $4.89 \pm 0.06^{\mathrm{bA}}$ & $5.49 \pm 0.04^{b C}$ \\
\hline & SBC2 & $5.74 \pm 0.05^{\mathrm{aD}}$ & $4.94 \pm 0.03 \mathrm{bcB}$ & $4.81 \pm 0.07^{\mathrm{bcA}}$ & $5.47 \pm 0.11^{\mathrm{bC}}$ \\
\hline \multirow{5}{*}{ Water activity } & SK & $0.968 \pm 0.005^{\mathrm{aD}}$ & $0.913 \pm 0.010^{\mathrm{aC}}$ & $0.829 \pm 0.017^{\mathrm{aB}}$ & $0.801 \pm 0.010^{\mathrm{aA}}$ \\
\hline & SCH1 & $0.973 \pm 0.003^{\mathrm{aD}}$ & $0.917 \pm 0.006^{\mathrm{aC}}$ & $0.835 \pm 0.010^{\mathrm{aB}}$ & $0.802 \pm 0.001^{\mathrm{aA}}$ \\
\hline & $\mathrm{SCH} 2$ & $0.972 \pm 0.006^{\mathrm{aD}}$ & $0.915 \pm 0.002^{\mathrm{aC}}$ & $0.830 \pm 0.003^{\mathrm{aB}}$ & $0.801 \pm 0.005^{\mathrm{aA}}$ \\
\hline & SBC1 & $0.968 \pm 0.005^{\mathrm{aD}}$ & $0.910 \pm 0.005^{\mathrm{aC}}$ & $0.830 \pm 0.005^{\mathrm{aB}}$ & $0.813 \pm 0.002^{\mathrm{aA}}$ \\
\hline & SBC2 & $0.969 \pm 0.004 \mathrm{aD}$ & $0.910 \pm 0.001 \mathrm{aC}$ & $0.831 \pm 0.001 \mathrm{aB}$ & $0.798 \pm 0.012^{\mathrm{aA}}$ \\
\hline
\end{tabular}

SK-control sample; SCH1—sample with $1 \%$ addition of chia seed; SCH2-sample with $2 \%$ addition of chia seed; SBC1—sample with $1 \%$ addition of black cumin seed; SBC2-sample with $2 \%$ addition of black cumin seed; means with the same letter a-d do not differ significantly $(p>0.05)$ within the variable in the same day (column); means with the same cover letter A-D do not differ significantly $(p>0.05)$ within the same variant of variable in different day (row).

As in the case of water content, the water activity in the samples decreased significantly throughout 30 days (Table 1). There were no significant differences within the different sausages regardless of the day of the study. The samples on Day 1 were characterized by water activity in the range of $0.968-0.973$, while on Day 30 , they were characterized by water activity in the range of $0.798-0.813$.

\subsection{The TBARS Results}

The TBARS results are reported in Table 2. During the first 10 days, no differences were observed between the sausage samples. In addition, the control sample and sample with black cumin addition suffered similar oxidation throughout the processing time. However, after Day 20, the samples with chia showed greater oxidative degradation than the other batches. With higher chia percentage, the oxidation was higher $(2.24(2 \%)$ vs. $1.38(1 \%)$ and $2.53(2 \%)$ vs. $1.31(1 \%)$ at 20 and 30 days, respectively). Solely the samples with chia underwent lipid oxidation over time. Both control and black cumin samples remained at the same level of oxidation during the whole study. 
Table 2. The evolution of color parameters, nitrosylmyoglobin, and TBARS content during the manufacturing process of dry fermented sausages.

\begin{tabular}{|c|c|c|c|c|c|}
\hline \multirow{2}{*}{ Parameter } & \multirow{2}{*}{ Treatment } & \multicolumn{4}{|c|}{ Processing Day } \\
\hline & & Day 1 & Day 10 & Day 20 & Day 30 \\
\hline \multirow{5}{*}{$\mathrm{L}^{*}$ color parameter } & SK & $49.24 \pm 1.73^{\mathrm{aB}}$ & $45.58 \pm 1.88^{\mathrm{aB}}$ & $37.44 \pm 1.56^{\mathrm{aA}}$ & $35.61 \pm 3.87^{\mathrm{aA}}$ \\
\hline & $\mathrm{SCH} 1$ & $47.43 \pm 1.53^{\mathrm{aAB}}$ & $51.99 \pm 2.22^{b B}$ & $43.41 \pm 1.29^{\mathrm{abA}}$ & $43.08 \pm 4.72^{\mathrm{bA}}$ \\
\hline & $\mathrm{SCH} 2$ & $47.95 \pm 2.34^{\mathrm{aAB}}$ & $51.74 \pm 0.88^{\mathrm{bB}}$ & $48.31 \pm 2.64^{\mathrm{bAB}}$ & $43.01 \pm 3.26^{\mathrm{bA}}$ \\
\hline & SBC1 & $45.17 \pm 1.87^{\mathrm{aB}}$ & $48.27 \pm 2.69^{a b B}$ & $42.96 \pm 3.41^{\mathrm{abB}}$ & $35.76 \pm 1.74^{\mathrm{aA}}$ \\
\hline & SBC2 & $44.61 \pm 1.80^{\mathrm{aB}}$ & $48.32 \pm 1.16^{\mathrm{abB}}$ & $42.40 \pm 6.51^{\mathrm{abAB}}$ & $37.07 \pm 3.59 \mathrm{abA}$ \\
\hline \multirow{5}{*}{$\mathrm{a}^{*}$ color parameter } & SK & $7.78 \pm 1.05^{\mathrm{abA}}$ & $9.34 \pm 0.84^{\mathrm{bA}}$ & $9.32 \pm 2.75^{b A}$ & $8.03 \pm 1.55^{b A}$ \\
\hline & $\mathrm{SCH} 1$ & $8.08 \pm 0.80^{\mathrm{bA}}$ & $9.85 \pm 1.11^{\mathrm{bA}}$ & $9.97 \pm 0.57^{b A}$ & $9.06 \pm 1.16^{\mathrm{bA}}$ \\
\hline & $\mathrm{SCH} 2$ & $9.08 \pm 1.35^{\mathrm{bA}}$ & $10.09 \pm 0.75^{\mathrm{bA}}$ & $7.73 \pm 0.54^{\mathrm{bA}}$ & $8.18 \pm 0.61^{\mathrm{bA}}$ \\
\hline & SBC1 & $5.85 \pm 0.96^{\mathrm{aA}}$ & $7.69 \pm 0.80^{a b A}$ & $5.73 \pm 0.81^{\mathrm{abA}}$ & $6.61 \pm 1.17^{\mathrm{abA}}$ \\
\hline & SBC2 & $5.55 \pm 0.69^{\mathrm{aA}}$ & $6.47 \pm 0.10^{\mathrm{aA}}$ & $4.42 \pm 0.40^{\mathrm{aA}}$ & $4.45 \pm 1.02^{\mathrm{aA}}$ \\
\hline \multirow{5}{*}{$\mathrm{b}^{*}$ color parameter } & SK & $9.27 \pm 0.43^{a b C}$ & $6.98 \pm 0.55^{\mathrm{abB}}$ & $6.77 \pm 1.14 \mathrm{bB}$ & $5.01 \pm 0.84^{\mathrm{abA}}$ \\
\hline & $\mathrm{SCH} 1$ & $10.13 \pm 0.78^{b C}$ & $8.08 \pm 0.60 \mathrm{bcB}$ & $7.00 \pm 1.53^{\mathrm{bAB}}$ & $5.48 \pm 1.07^{\mathrm{bA}}$ \\
\hline & $\mathrm{SCH} 2$ & $10.64 \pm 0.46^{\mathrm{bC}}$ & $9.07 \pm 0.46^{\mathrm{cB}}$ & $5.90 \pm 0.60^{\mathrm{bA}}$ & $6.05 \pm 1.32^{b A}$ \\
\hline & SBC1 & $7.95 \pm 0.75^{\mathrm{aC}}$ & $6.38 \pm 0.74^{\mathrm{aB}}$ & $3.70 \pm 0.31^{\mathrm{aA}}$ & $4.29 \pm 0.91^{\mathrm{aA}}$ \\
\hline & SBC2 & $7.55 \pm 0.51^{\mathrm{aC}}$ & $6.22 \pm 0.77^{\mathrm{aB}}$ & $3.46 \pm 0.20^{\mathrm{aA}}$ & $3.91 \pm 1.07^{\mathrm{aA}}$ \\
\hline \multirow{5}{*}{$\Delta \mathrm{E}$} & SK & & & & \\
\hline & $\mathrm{SCH} 1$ & $3.14 \pm 1.12^{a}$ & $7.30 \pm 2.35^{a}$ & $6.91 \pm 2.07^{a}$ & $9.85 \pm 2.13^{b}$ \\
\hline & $\mathrm{SCH} 2$ & $3.68 \pm 1.70^{\mathrm{a}}$ & $6.66 \pm 2.17^{a}$ & $11.37 \pm 2.64^{\mathrm{a}}$ & $7.79 \pm 4.44^{\mathrm{ab}}$ \\
\hline & SBC1 & $5.21 \pm 2.26^{\mathrm{a}}$ & $4.35 \pm 2.03^{\mathrm{a}}$ & $8.30 \pm 2.46^{\mathrm{a}}$ & $4.67 \pm 1.73^{\mathrm{a}}$ \\
\hline & SBC2 & $5.75 \pm 1.14^{\mathrm{a}}$ & $4.69 \pm 1.63^{a}$ & $10.63 \pm 2.24^{a}$ & $5.54 \pm 2.63^{\mathrm{ab}}$ \\
\hline \multirow{5}{*}{ Nitrosylmyoglobin $\left(\mathrm{mg} \mathrm{kg}^{-1}\right)$} & SK & $11.74 \pm 3.56^{\mathrm{aA}}$ & $13.97 \pm 0.85^{\mathrm{aA}}$ & $25.81 \pm 3.97^{\mathrm{aB}}$ & $28.56 \pm 5.04^{\mathrm{aB}}$ \\
\hline & SCH1 & $14.93 \pm 2.20^{\mathrm{aA}}$ & $38.47 \pm 0.54^{\mathrm{bB}}$ & $48.57 \pm 2.54^{\mathrm{bcC}}$ & $56.07 \pm 4.65^{\mathrm{bC}}$ \\
\hline & $\mathrm{SCH} 2$ & $15.32 \pm 1.19^{\mathrm{aA}}$ & $40.07 \pm 1.01 \mathrm{bBC}$ & $42.68 \pm 6.51^{\mathrm{bC}}$ & $33.54 \pm 12.61^{\mathrm{aB}}$ \\
\hline & SBC1 & $16.57 \pm 1.77^{\mathrm{aA}}$ & $39.34 \pm 1.66^{\mathrm{bB}}$ & $52.49 \pm 3.59 \mathrm{cC}$ & $58.24 \pm 1.74 \mathrm{bcC}$ \\
\hline & SBC2 & $18.17 \pm 1.65^{\mathrm{aA}}$ & $44.03 \pm 1.80^{\mathrm{bB}}$ & $62.35 \pm 2.72 \mathrm{dC}$ & $66.55 \pm 2.63^{\mathrm{cC}}$ \\
\hline \multirow{5}{*}{ TBARS $\left(\mathrm{mg} \mathrm{kg}^{-1}\right)$} & SK & $0.64 \pm 0.05^{\mathrm{aA}}$ & $0.77 \pm 0.22^{\mathrm{aA}}$ & $0.87 \pm 0.29 \mathrm{aA}$ & $0.95 \pm 0.09 \mathrm{aA}$ \\
\hline & SCH1 & $0.68 \pm 0.06^{\mathrm{aA}}$ & $0.77 \pm 0.14^{\mathrm{aAB}}$ & $1.38 \pm 0.10^{\mathrm{aC}}$ & $1.31 \pm 0.14^{\mathrm{aBC}}$ \\
\hline & $\mathrm{SCH} 2$ & $0.70 \pm 0.08^{\mathrm{aA}}$ & $0.98 \pm 0.18^{\mathrm{aA}}$ & $2.24 \pm 0.89 \mathrm{bB}$ & $2.53 \pm 1.00^{\mathrm{bB}}$ \\
\hline & SBC1 & $0.74 \pm 0.08^{\mathrm{aA}}$ & $0.90 \pm 0.14^{\mathrm{aA}}$ & $1.15 \pm 0.08^{\mathrm{aA}}$ & $1.03 \pm 0.08^{\mathrm{aA}}$ \\
\hline & SBC2 & $0.79 \pm 0.06^{\mathrm{aA}}$ & $1.11 \pm 0.19^{\mathrm{aA}}$ & $1.11 \pm 0.04^{\mathrm{aA}}$ & $1.19 \pm 0.11^{\mathrm{aA}}$ \\
\hline
\end{tabular}

SK-control sample; SCH1—sample with 1\% addition of chia seed; SCH2—sample with 2\% addition of chia seed; SBC1—sample with $1 \%$ addition of black cumin seed; SBC2 - sample with $2 \%$ addition of black cumin seed; means with the same letter a-d do not differ significantly $(p>0.05)$ within the variable in the same day (column); means with the same cover letter A-C do not differ significantly $(p>0.05)$ within the same variant of variable in different day (row).

\subsection{The Results of Instrumental Color Measurement and Nitrosylmyoglobin Content}

The results of color parameters $\left(\mathrm{L}^{*}, \mathrm{a}^{*}, \mathrm{~b}^{*}\right)$ are also given in Table 2. In general, the lightness $\left(\mathrm{L}^{*}\right)$ experimented a reduction from Day 1 to 30 in all samples $(49.24 \mathrm{vs} .35 .61$ (SK), 47.43 vs. 43.08 (SCH1), 47.95 vs. 43.01 (SCH2), 45.17 vs. 35.76 (SB1), and 4.61 vs. 37.07 (SBC2)). Nevertheless, the highest values were reached at Day 10 for SCH1 (51.99), SCH2 (51.74), SBC1 (48.27), and SBC2 (48.32), and at Day 1 for SK (49.24). No differences in L* 
were observed among the different samples during the first day of the ripening process, for which values ranged from 44.61 to 49.24 . However, on the rest of the days, SCH sausages had higher values than SBC sausages. In turn, SBC was characterized by the slightly higher lightness at 10 and 20 days compared to the SK sample.

The same redness values $\left(\mathrm{a}^{*}\right)$ was maintained throughout the time in all batches (SK (7.78-9.34), SCH1 (8.08-9.97), SCH2 (7.73-10.09), SBC1 (5.73-7.69), and SBC2 (4.42-6.47)). The sausages with the addition of black cumin presented the lowest $\mathrm{a}^{*}$ at any of the days, whereas the sausages elaborated with chia seeds had the greatest redness value. Even the control sample had similar value of $a^{*}$ parameter compared to the sausages with chia seeds.

Regarding yellowness $\left(b^{*}\right)$, this parameter decreased progressively with time in all samples, except for $\mathrm{SCH} 2, \mathrm{SBC} 1$, and $\mathrm{SBC} 2$, where they showed the same degree of $\mathrm{b}^{*}$ from days 20 to 30 (SK (9.27-5.01), SCH1 (10.13-5.48), SCH2 (10.64-6.05), SBC1 (7.95-4.29), and SBC2 (7.55-3.91)). In case of the $b^{*}$ parameter, the same trend as for $a^{*}$ parameter was observed. The SBC samples showed the lowest $b^{*}$ values, while samples with chia seed were characterized by the highest $b^{*}$ color parameter values.

The color differences $(\Delta \mathrm{E})$ between control and test samples showed that the greatest color changes took place at Day 20. At this day, the color changes for the samples ranged from 6.91 to 11.37. The greatest color changes were shown between the control and SCH2 sample. The values $\Delta \mathrm{E}$ higher than 5 mean that an observer notices two different colors for samples.

The content of nitrosylmyoglobin increased with time, leading to the greatest amount on the last day (Table 2) with the exception of the $\mathrm{SCH} 2$ samples. The samples with chia seed were characterized by the highest content of nitrosylmyoglobin at Day $20\left(45.68 \mathrm{mg} \mathrm{kg}^{-1}\right)$. No differences among the sausages were observed during the first day. SK sample showed the lowest content of this compound on any of the days studied $(11.74,13.97,25.81$, and $28.56 \mathrm{mg} \mathrm{kg}^{-1}$ at $1,10,20$, and 30 days), whereas the SBC samples showed the highest values. Slightly more concentration was reached in the sausages with $2 \%$ of black cumin seeds (18.17 vs. $16.57,44.03$ vs. $39.34,62.35$ s. 52.49 , and 66.55 vs. $58.24 \mathrm{mg} \mathrm{kg}^{-1}$ at 1, 10, 20, and 30 days).

\subsection{The Results of Microbiological Analyzes}

Regarding the changes on microbial growth of the Enterobacteriaceae (Figure 2), from Day 1 onwards, the Gram-negative bacteria decreased, reaching the minimum levels at Day $10\left(1.51,1.04,0.66,1.11\right.$, and $0.70 \log \mathrm{CFU} \mathrm{g}^{-1}$ for SK, SCH1, SCH2, SBC1, and SBC2, respectively). It can be highlighted that the control samples presented the highest number of colonies on any of the days, exceeding $5 \log$ CFU g ${ }^{-1}$ on day 0 and almost $3 \log$ CFU g ${ }^{-1}$ on Day 30. On the other hand, the addition of a higher percentage of seeds resulted in a decrease of Enterobacteriaceae, achieving the lowest values on $\mathrm{SCH} 2$ sausages at 10 and 20 days $\left(0.66(2 \%)\right.$ vs. $1.03(1 \%)$ and $2.11(2 \%)$ vs. $\left.2.95(1 \%) \log \mathrm{CFU} \mathrm{g}^{-1}\right)$ and SBC2 $\left(1.32(2 \%)\right.$ vs. $\left.1.83(1 \%) \log \mathrm{CFU} \mathrm{g}{ }^{-1}\right)$ at 30 days. Furthermore, comparing the different seeds with the same percentage of addition, chia seeds provided lower values in all cases, excepting the $2 \%$ addition at Day 30 , where black cumin achieved better results.

Concerning the lactic acid bacteria growth, the proliferation increased ongoing the fermentation process, where the amount surpassed the $7 \log C F U g^{-1}$ on days 10,20 , and 30 in all cases except for the control, which had the same amount of LAB on the first and last day of ripening. Due to food safety, we also determined the content of L. monocytogenes. None of samples contained this microorganism $\left(<10 \mathrm{CFU} \mathrm{g}{ }^{-1}\right)$. 
$\square$ Day $30 \quad \square$ Day $20 \quad \square$ Day $10 \quad$ Day 1
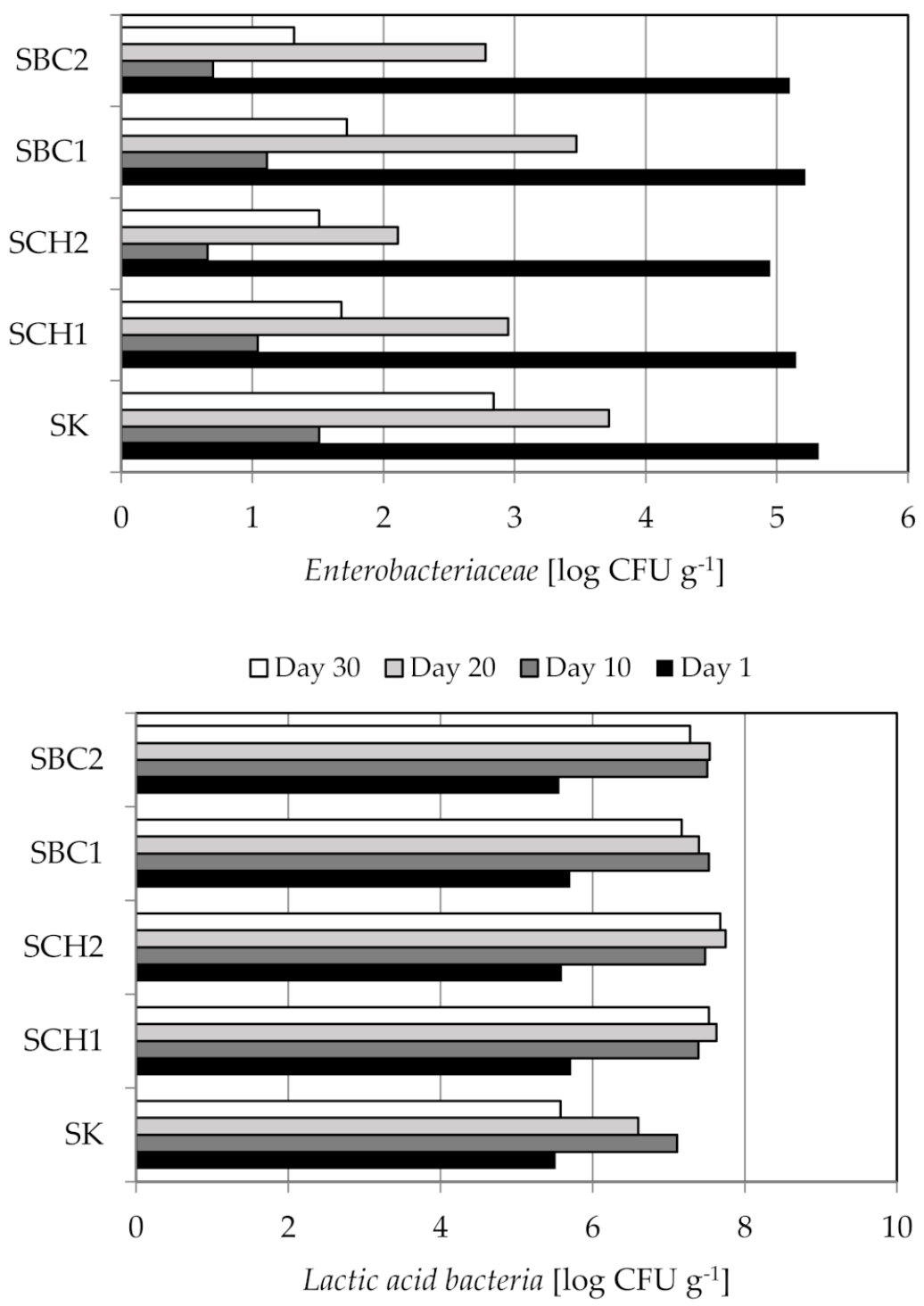

\begin{tabular}{ccc}
\hline Parameter & Treatment & Day 30 \\
\hline $\begin{array}{c}\text { L. monocytogenes } \\
{[\text { [CFU g-1] }}\end{array}$ & $S K$ & $<10$ \\
\cline { 2 - 3 } & $S C H 1$ & $<10$ \\
\cline { 2 - 3 } & $S C H 2$ & $<10$ \\
\cline { 2 - 3 } & $S B C 1$ & $<10$ \\
\cline { 2 - 3 } & $S B C 2$ & $<10$ \\
\hline
\end{tabular}

Figure 2. The results of microbiological analyzes during the manufacturing process of dry fermented sausages. SK — control sample; SCH1—sample with $1 \%$ addition of chia seed; $\mathrm{SCH} 2$ - sample with $2 \%$ addition of chia seed; SBC1—sample with $1 \%$ addition of black cumin seed; SBC2—sample with $2 \%$ addition of black cumin seed.

\subsection{Results of Cluster and PCA Analysis}

Figure 3 shows a cluster analysis dendogram that takes into account all types of samples (factors are: type of supplement, its level, and day). In the course of the analysis, a 
group of six samples (the first from the top) was distinguished, especially from the study on Day 1. SK sample at Day 20 (SK_20) slightly differs from the others in this group. The remaining trials (10,20, and 30 days) form a separate group. The presented data clearly indicate that the storage time modifies the properties of the product.

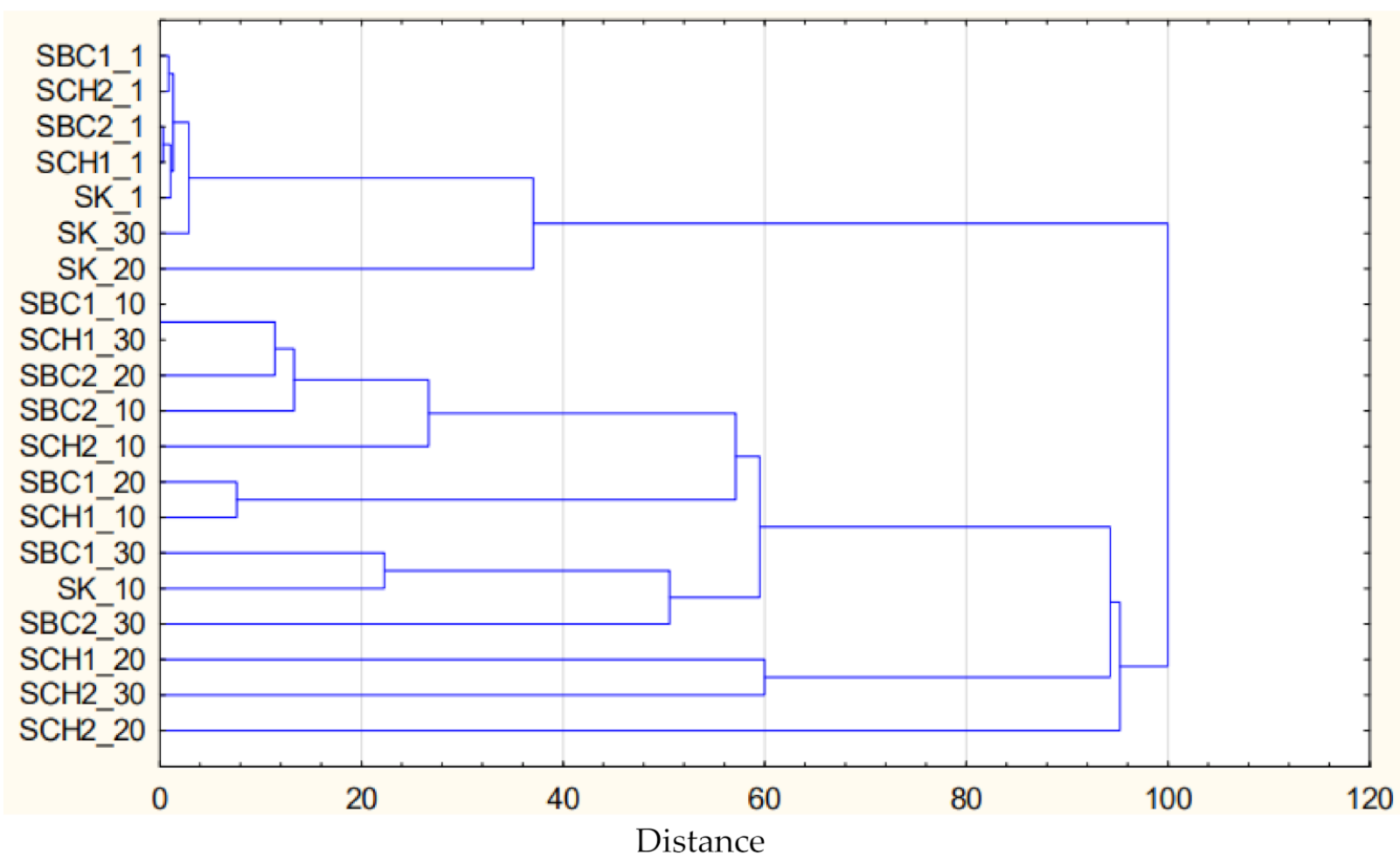

Figure 3. Cluster analysis dendogram. SK—control sample; SCH1—sample with 1\% addition of chia seed; SCH2—sample with $2 \%$ addition of chia seed; SBC1—sample with $1 \%$ addition of black cumin seed; SBC2—sample with $2 \%$ addition of black cumin seed.

Figure 4 shows the loading plot of the measurements of sausages quality. In the case of the samples with chia seed, the first component (p1) is negatively affected by $\mathrm{pH} \mathrm{a}^{*}$ and positively affected by $\mathrm{L}^{*}$. On the other hand, the second component (p2) is determined by the negative influence of NOMb, TBARS, and positive- $b^{*}, W C$, and $a_{w}$. There is a positive correlation for the parameters NOMb and TBARS, as well as WC, and $\mathrm{w}$ and $\mathrm{b}^{*}$. A negative correlation was also observed between $\mathrm{NOMb}$ and the parameters describing water availability $\left(\mathrm{a}_{\mathrm{w}}\right.$ and WC). A similar relationship applies to TBARS and $\mathrm{pH}$. Interestingly, there is also a weak correlation between the color parameters $\left(\mathrm{a}^{*}, \mathrm{~L}^{*}\right)$ and the parameters describing water availability, i.e., $\mathrm{a}_{\mathrm{W}}$ and WC. Similarly, low correlation applies to $\mathrm{pH}$ and parameters such as $\mathrm{L}^{*}, \mathrm{~b}^{*}$, and WC. In the case of samples with black cumin, the first component is influenced most positively by $\mathrm{pH}$, $\mathrm{a}^{*}$ color parameter, and negatively by $L^{*}$ parameter. On the other hand, the second component is determined by the negative influence of NOMb and TBARS and the positive influence of $b^{*}, W C$, and $a_{w}$. There is a clear positive correlation for the NOMb and TBARS parameters, as well as for $\mathrm{a}^{*}$ and $\mathrm{pH}$, and $\mathrm{WC}$ and $\mathrm{a}_{\mathrm{w}}$. As expected, $\mathrm{NOMb}$ and TBARS are related to oxidation, and water activity is determined by WC. The $\mathrm{pH}$ value influences the redness $\left(\mathrm{a}^{*}\right)$. It is also worth noting the negative correlation between $\mathrm{NOMb}$ and $\mathrm{a}^{*}$, as well as TBARS and $\mathrm{pH}$. It is also interesting that there is no significant correlation between the color parameters and the parameters describing water availability, i.e., $\mathrm{a}_{\mathrm{w}}$ and WC. 


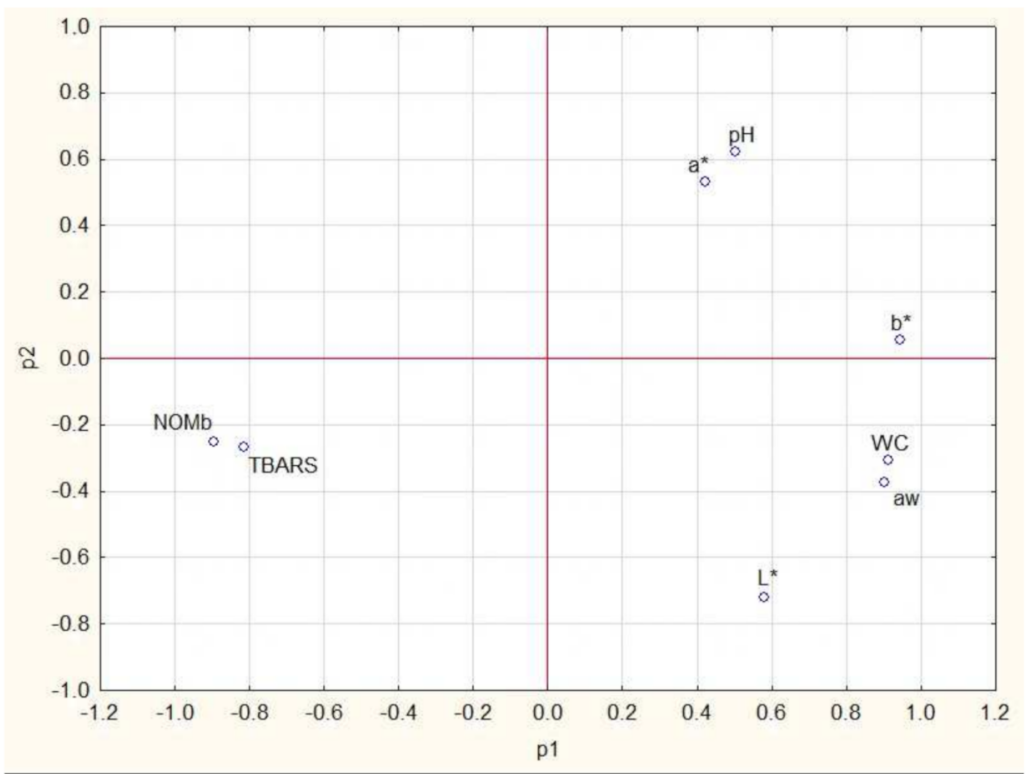

(a)

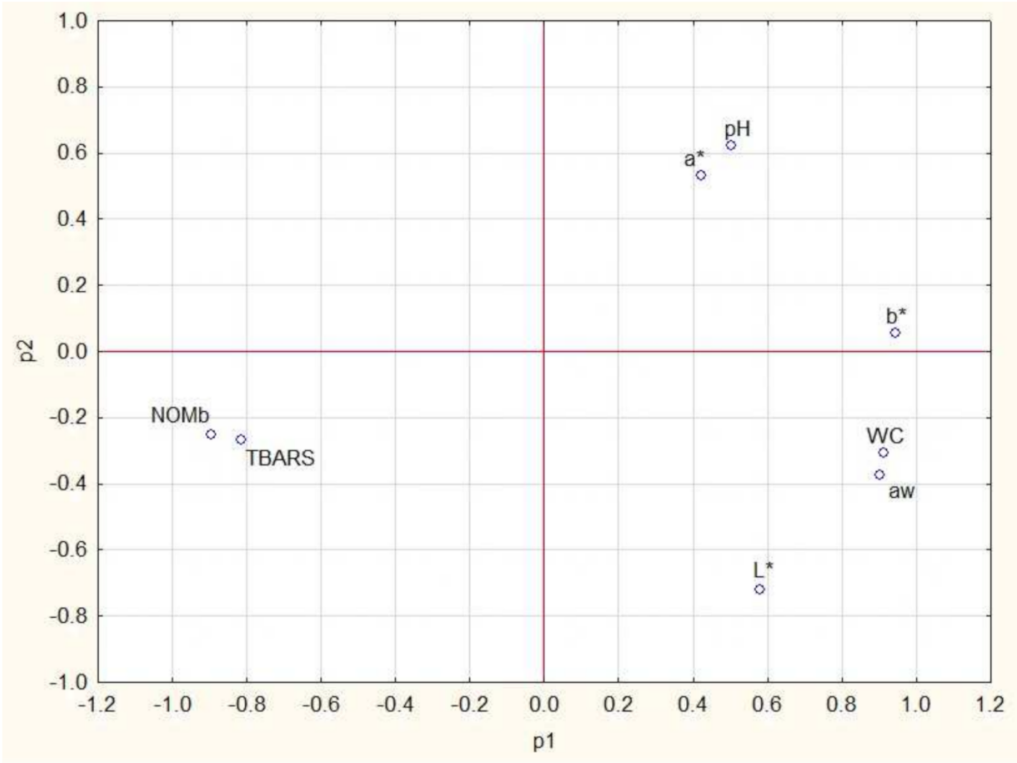

(b)

Figure 4. Loadings for the two principal components. (a) for samples with chia seed addition; (b) for samples with black cumin seed addition.

\subsection{Biogenic Amines Content}

Table 3 reports the amount in $\mathrm{mg} \mathrm{g}^{-1}$ of the identified amines at the last day of the experiment. The most abundant biogenic amines present in all sausages were the tyramine and putrescine. Moreover, the samples with seeds addition had a higher concentration of BAs compared to the control sausage. The highest concentration of these organic compounds was achieved with the incorporation of chia seeds followed by the black cumin. In addition, it can be seen that with a higher percentage of chia seeds added, the amount of tyramine slightly increased $\left(0.194\right.$ and $0.223 \mathrm{mg} \mathrm{g}^{-1}$ for the additions of $1 \%$ and $2 \%$, respectively). However, the opposite behavior was observed in the spermine where the control samples had the maximum levels $\left(0.089 \mathrm{mg} \mathrm{g}^{-1}\right)$ and the black cumin the lowest $(0.060(1 \%)$ and $0.059(2 \%))$. No significant differences were found in cadaverine, where the values ranged from $0.099-0.148 \mathrm{mg} \mathrm{g}^{-1}$. All sausages showed similar amounts of spermidine except for $\mathrm{SCH} 2$, which was characterized by higher cadaverine content 
$\left(0.016 \mathrm{mg} \mathrm{g}^{-1}\right)$. Regarding the agmatine, a natural aliphatic polyamine produced from arginine, it was only detected in control samples at a concentration of $0.105 \mathrm{mg} \mathrm{g}^{-1}$.

Table 3. The biogenic amines content at 30 day of manufacturing process of dry fermented sausages [mg g $\left.\mathrm{m}^{-1}\right]$.

\begin{tabular}{ccccccc}
\hline & Tyramine & Putrescine & Cadaverine & Spermidine & Agmatine & Spermine \\
\hline SK & $0.094 \pm 0.066^{a}$ & $0.048 \pm 0.023^{a}$ & $0.099 \pm 0.051^{a}$ & $0.010 \pm 0.003^{a}$ & $0.105 \pm 0.012$ & $0.089 \pm 0.036^{c}$ \\
\hline SCH1 & $0.194 \pm 0.080^{a b}$ & $0.114 \pm 0.058^{c}$ & $0.103 \pm 0.107^{a}$ & $0.010 \pm 0.005^{a}$ & nd & $0.055 \pm 0.028^{a b c}$ \\
\hline SCH2 & $0.223 \pm 0.053^{\mathrm{b}}$ & $0.147 \pm 0.009^{\mathrm{c}}$ & $0.144 \pm 0.043^{\mathrm{a}}$ & $0.016 \pm 0.001^{\mathrm{b}}$ & $\mathrm{nd}$ & $0.070 \pm 0.003^{\mathrm{bc}}$ \\
\hline $\mathrm{SBC} 1$ & $0.147 \pm 0.028^{\mathrm{ab}}$ & $0.104 \pm 0.005^{\mathrm{b}}$ & $0.120 \pm 0.046^{\mathrm{a}}$ & $1.010 \pm 0.001^{\mathrm{a}}$ & $\mathrm{nd}$ & $0.060 \pm 0.003^{\mathrm{ab}}$ \\
\hline SBC2 & $0.166 \pm 0.056^{\mathrm{ab}}$ & $0.108 \pm 0.004^{\mathrm{b}}$ & $0.148 \pm 0.066^{\mathrm{a}}$ & $0.011 \pm 0.001^{\mathrm{a}}$ & $\mathrm{nd}$ & $0.059 \pm 0.003^{\mathrm{a}}$ \\
\hline
\end{tabular}

nd-not detected; SK-control sample; SCH1—sample with $1 \%$ addition of chia seed; SCH2—sample with $2 \%$ addition of chia seed; SBC1 - sample with $1 \%$ addition of black cumin seed; SBC2 — sample with $2 \%$ addition of black cumin seed; means with the same letter $\mathrm{a}-\mathrm{c}$ do not differ significantly $(p>0.05)$ within the variable (column).

\section{Discussion}

\subsection{Physicochemical Parameters (Water Content, $\mathrm{pH}$, Water Activity)}

The addition of chia or black cumin did not exert any effect on water content or water activity changes since no significant differences were found compared to the control. Our data differed from other authors whose results revealed that the incorporation of chia seeds into chicken sausages facilitates the moisture reduction [37]. In addition, they observed that with a higher percentage of seeds, the moisture is lower at day $0(63.24 \%, 62.57 \%$, and $61.32 \%$ for $2 \%, 4 \%$, and $6 \%$ of chia seeds). The same trend was observed in pork dry-cured sausages [38] at Day 3 of storage, where the $6 \%$ chia sausages showed a lesser percentage of moisture than the control samples (33.13\% vs $42.48 \%)$. As in our experiment, they also found a decrease in water activity with time. The amount of chia did not affect the $a_{w}$ values. There were no differences in water content in another study of frankfurters with $3 \%$ chia seeds concerning the control samples [24]. The $\mathrm{pH}$ decreased in all the samples during the ripening process. This tendency could be explained due to the growth of LAB. The main function of this bacteria is to reduce the $\mathrm{pH}$ through the production of lactic acid from the fermentation of sugars [39]. However, the production of acids also depends on the concentration and type of sugars added and the diameter of the sausages [40]. The lowest $\mathrm{pH}$ achieved with chia sausages on Day 20 of the production process is due to the highest proliferation of LAB in this type of sausages. In any cases, it has been reported that the incorporation of chia seeds lowered the $\mathrm{pH}$ levels in frankfurters after 14 and 21 days [24]. On the other hand, the introduction of chia seeds in pork dry-cured sausages did not modify the $\mathrm{pH}$ over time, though on Day 0 , the $\mathrm{pH}$ was significantly lower than the control samples (5.63 vs. 5.78) [38].

\subsection{Lipid Oxidation Analyzes}

The TBARS method is commonly used as a marker of lipid peroxidation to control lipidic changes during the processing of fermented sausages. At the beginning of the study up to Day 20, there were no differences between the sausages on TBARS values. Moreover, TBARS values did not alter in both control and sausages with black cumin throughout the study. Thus, the incorporation of black cumin did not affect lipid peroxidation. The benefits of chia seeds, which are an excellent source of antioxidants, are well-known. However, the incorporation of chia seeds into dry fermented sausages led to a significant increase in malondialdehyde concentration after 20 days, pointing to these sausages as the most oxidized. Even in the sausages with higher chia content, the oxidation was greater. This could be explained due to the higher concentration of polyunsaturated fatty acids in chia. Additionally, malondialdehyde is mainly formed from linolenic acid oxidation, a compound present in chia seeds. Furthermore, aldehydes from sugars and phenolic compounds may interfere on TBARS [41]. Nonetheless, these findings are in contradiction 
with other authors, who found that chia seeds retard oxidation. Specifically, sausages with $3 \%$ chia suffered less oxidation than the control (roughly 1.6 less) [24]. The same trend was observed in dry-cured sausages (around 1.2 times lower, Day 3) [38] as well as in camel burgers (abound 1.3 times lower, Day 12) [28].

\subsection{Instrumental Color Parameters and Nitrosylmyoglobin Content}

Color is one of the foremost sensory attributes for meat and meat products consumers since it is associated with freshness and quality [42,43]. All sausages suffered a lightness and yellowness reduction from Day 1 to Day 30. On the last day, both the control sausage and the sausages with black cumin showed similar values of $\mathrm{L}^{*}$ parameter, being significantly lower than the sausages with chia seed addition. The redness ( $a^{*}$ parameter) remained invariable in every sample during the whole processing period. The control sausage and sausages with chia seed exhibited the highest $b^{*}$, whereas the black cumin addition provided the lowest value. Our results differed from chia frankfurters [24], which presented lower $\mathrm{a}^{*}$ and $\mathrm{L}^{*}$ than control frankfurters at Day 21. Moreover, while $\mathrm{L}^{*}$ decreased by the time, $a^{*}$ and $b^{*}$ showed similar values at Days 0 and 21 in the case of chia samples. During fermentation, the proliferation of Gram-positive microorganisms provide color stabilization due to their ability to form a nitrosylmyoglobin complex through the reaction of nitric oxide with myoglobin. This compound is responsible for the unique color in cured meat $[44,45]$. In our study, the nitrosylmioglobin content recorded increased broadly along the time. Sausages with seeds added provided the greatest results, especially those with higher proportion of black cumin added. Łaszkiewicz et al. [46] pointed out that the lactic acid bacteria contribute to the synthesis of nitrosyl pigments in cured poultry meat. Other researchers explained the same phenomenom [42,43]. Therefore, our results are well-correlated with the acid lactic bacteria since the largest values for nitrosylmyoglobin were observed in the sausages with the highest lactic acid bacteria content.

\subsection{Microbiological Analyzes}

The Enterobacteriaceae could have been derived from the raw tissues, contaminated in the slaughterhouses during the slaughtering and quartering of the animal. The Enterobacteriaceae counts decreased in all samples until Day 10 of ripening, increasing in the following 20 days before again decreasing until the end of the processing. Sausages with seed additions were characterized by a lower Enterobacteriaceae content in comparison to the control. This fact indicated that chia and black cumin had a positive effect on reducing the tested bacterial count. Studies by Duda-Chodak et al. [47] proved that kaempferol and quercetin as the main Salvia hispanica bioactives representatives could exert a strong and negative effect on the development of both opportunistic and truly pathogenic microorganisms, including Enterobacteriaceae. Traditionally, fermented sausages are manufactured using lactic acid bacteria and coagulase-negative staphylococci that are naturally present in meat. During the fermentation, there is an increase in the lactic acid bacteria count. As expected, the LAB count at the end of ripening was higher than on the first day, excluding the control, where the first and the last day showed the same growth. This fact suggests that the addition of chia or black cumin seed enhances the proliferation of the LAB. LAB are safe microorganisms; they can inhibit pathogens, producing a wide range of inhibitory compounds such as bacteriocins, carbon dioxide, diacetyl, ethanol, hydrogen peroxide, and lactic acid [48]. The rapid growth of LAB is important to become dominant and competitive against foodborne pathogens such as Bacillus cereus, Clostridium perfringens, Listeria monocytogenes, and Staphylococcus aureus. As mentioned before, the principal role of LAB is to acidify the matrix through lactic acid generated by the fermentation of carbohydrates [40]. One of the most frequently detected pathogens in dry fermented sausages is the L. monocytogenes. The optimal conditions for their growth are $\mathrm{pH}$ values between $6.0-8.0$ and water activities above 0.92, though they can survive even at lower and higher $\mathrm{pH}$ (4.5-9.0). Thus, the drying step is crucial to reduce water activity and consequently minimize the survival of L. monocytogenes [49]. After 30 days, none of the sausages contained these 
bacteria $\left(<10 \mathrm{CFU} \mathrm{g}^{-1}\right)$. The reason is because after the ripening stage, the water activities of sausages ranged from $0.813-0.798$, and $\mathrm{pH}$ was under 6.0 . Furthermore, L. monocytogenes could not compete due to the high population of LAB [40,49].

\subsection{Biogenic Amines Content}

Fermented and protein-rich foods are prone to forming toxic nitrogenous bases such as biogenic amines. These low-molecular-weight compounds are generated due to the microbial decarboxylation of amino acids through substrate-specific decarboxylase enzymes $[50,51]$. Some authors reported that tyramine, putrescine, and cadaverine are the predominant biogenic amines in fermented foods [51,52]. As we could see, these compounds were those with the highest concentration in experimental sausages ranging from $0.094-0.223 \mathrm{mg} \mathrm{g}^{-1}$ (tyramine), $0.048-0.147 \mathrm{mg} \mathrm{g}^{-1}$ (putrescine), and $0.099-0.148 \mathrm{mg} \mathrm{g}^{-1}$ (cadaverine). Among these biogenic amines, tyramine has attracted special consideration due to its potential health risks at high levels. It is synthetized by the fermentative microbial population of lactic acid bacteria [53]. For this reason, sausage samples had a high level of tyramine since the growth of lactic acid bacteria increased considerably during the ripening process. Our results are well-correlated with the microbial of lactic acid bacteria since the control (SK) had both the lowest concentration of tyramine and the lowest growth of lactic acid bacteria. LAB and Enterobacteriaceae are capable of forming biogenic amines [54], though the LAB are the main producers [55]. Therefore, samples with a higher bacterial population are expected to contain more amines. However, the aliphatic diamines cadaverine and putrescine could potentiate the adverse effects of tyramine [56]. These substances are formed during food processing and storage by the action of bacteria. As BAs are indicators of the microbiological quality of food, their identification and quantification are important [57]. Agmatine can be metabolized to putrescine, the spermine and spermidine precursor [58]. The aminogenesis is strongly influenced by many factors, though the most relevant is the microbiological quality of raw material (decarboxylase activity is mainly attributed to enterobacteriaceae, pseudomonadaceae, micrococcaceae, lactic acid bacteria, etc.), which can vary in each production batch. Furthermore, the characteristics of the raw material (composition, ion strength, $\mathrm{pH}$, etc.), ingredients, additives, and the processing and storage conditions are also crucial factors that produce variations in the content of the different biogenic amines. Perhaps, due to the raw meat employed, the biogenic content in all sausages was quite higher compared with other studies [59]. Although they are considered a food hazard, there is no threshold for biogenic amines in European legislation, except for histamine in fish [60]. Biogenic amines are thermostable; therefore, after their formation, their elimination is quite difficult. Hence, it is critical to avoid their presence by employing appropriate materials and conditions to ensure food quality $[52,61,62]$. In addition, the fast acidification caused by negative amino decarboxylase cultures reduces the development of biogenic amines in sausages [48].

\section{Conclusions}

The incorporation of plant material, rich in bioactive compounds, in the preparation of fermented meat products is one of the strategies to develop innovative meat products with an improved nutritional profile. Chia and black cumin seed additions promoted changes in characteristics of traditional fermented sausages with reduced nitrites during 30 days of production. The addition of seeds caused a greater reduction in the $\mathrm{pH}$ of the sausages during the production process. The lowest $\mathrm{pH}$ and the highest $\mathrm{LAB}$ content were achieved with sausages with chia seed on the last day of the production process. Additionally, the largest values for nitrosylmyoglobin were observed in the sausages with the highest lactic acid bacteria content (samples with chia and black cumin seed addition), which confirms that the lactic acid bacteria contribute to the synthesis of nitrosyl pigments. Chia and black cumin seed incorporation in fermented sausages reduced Enterobacteriaceae; however, it affected higher concentration of BAs. Chia and black cumin appear to have a similar effect on the quality of fermented sausages. Generally, no significant differences were found in 
the values of most of the parameters assessed for the samples with $1 \%$ and $2 \%$ addition of seeds. The obtained results indicate that this plant material can be used as a natural additive in the production of fermented sausages with improved nutritional value.

Author Contributions: Conceptualization, M.K.; methodology, M.K. and D.M.S.; formal analysis, P.B. and M.K.; investigation, P.B., E.S., and M.Ż.; writing-original draft preparation, M.K. and P.B., writing-review and editing, J.M.L.; supervision, M.K. All authors have read and agreed to the published version of the manuscript.

Funding: This research received no external funding.

Institutional Review Board Statement: Not applicable.

Informed Consent Statement: Not applicable.

Data Availability Statement: Not applicable.

Conflicts of Interest: The authors declare no conflict of interest.

\section{References}

1. FAOSTAT 2019. Available online: http://www.fao.org/faostat/en/\#data/QL (accessed on 18 August 2021).

2. Huang, Y.; Cao, D.; Chen, Z.; Chen, B.; Li, J.; Guo, J.; Wei, Q. Red and processed meat consumption and cancer outcomes: Umbrella review. Food Chem. 2021, 356, 129697. [CrossRef] [PubMed]

3. Borrajo, P.; Pateiro, M.; Gagaoua, M.; Franco, D.; Zhang, W.; Lorenzo, J.M. Evaluation of the antioxidant and antimicrobial activities of porcine liver protein hydrolysates obtained using alcalase, bromelain, and papain. Appl. Sci. 2020, 10, 2290. [CrossRef]

4. Manessis, G.; Kalogianni, A.I.; Lazou, T.; Moschovas, M.; Bossis, I.; Gelasakis, A.I. Plant-derived natural antioxidants in meat and meat products. Antioxidants 2020, 9, 1215. [CrossRef] [PubMed]

5. Arslan, B.; Soyer, A. Effects of chitosan as a surface fungus inhibitor on microbiological, physicochemical, oxidative and sensory characteristics of dry fermented sausages. Meat Sci. 2018, 145, 107-113. [CrossRef] [PubMed]

6. Gallego, M.; Mora, L.; Escudero, E.; Toldrá, F. Bioactive peptides and free amino acids profiles in different types of European dry-fermented sausages. Int. J. Food Microb. 2018, 276, 71-78. [CrossRef]

7. Karwowska, M.; Kononiuk, A.D.; Borrajo, P.; Lorenzo, J.M. Comparative Studies on the Fatty Acid Profile and Volatile Compounds of Fallow Deer and Beef Fermented Sausages without Nitrite Produced with the Addition of Acid Whey. Appl. Sci. 2021, 11, 1320. [CrossRef]

8. Mikami, N.; Tsukada, Y.; Pelpolage, S.W.; Han, K.H.; Fukushima, M.; Shimada, K. Effects of Sake lees (Sake-kasu) supplementation on the quality characteristics of fermented dry sausages. Heliyon 2020, 6, e03379. [CrossRef]

9. Balamurugan, S.; Gemmell, C.; Lau, A.T.Y.; Arvaj, L.; Strange, P.; Gao, A.; Barbut, S. High pressure processing during drying of fermented sausages can enhance safety and reduce time required to produce a dry fermented product. Food Contr. 2020, 113, 107224. [CrossRef]

10. Chen, Q.; Hu, Y.; Wen, R.; Wang, Y.; Qin, L.; Kong, B. Characterisation of the flavour profile of dry fermented sausages with different $\mathrm{NaCl}$ substitutes using HS-SPME-GC-MS combined with electronic nose and electronic tongue. Meat Sci. 2021, 172, 108338. [CrossRef]

11. Bis-Souza, C.V.; Pateiro, M.; Domínguez, R.; Lorenzo, J.M.; Penna, A.L.B.; da Silva Barretto, A.C. Volatile profile of fermented sausages with commercial probiotic strains and fructooligosaccharides. J. Food Sci. Technol. 2019, 56, 5465-5473. [CrossRef]

12. Cao, C.C.; Feng, M.Q.; Sun, J.; Xu, X.L.; Zhou, G.H. Screening of lactic acid bacteria with high protease activity from fermented sausages and antioxidant activity assessment of its fermented sausages. CyTA-J. Food 2019, 17, 347-354. [CrossRef]

13. Yu, D.; Feng, M.Q.; Sun, J. Influence of mixed starters on the degradation of proteins and the formation of peptides with antioxidant activities in dry fermented sausages. Food Contr. 2021, 123, 107743. [CrossRef]

14. Zhao, B.; Zhou, H.; Zhang, S.; Pan, X.; Li, S.; Zhu, N.; Chen, W. Changes of protein oxidation, lipid oxidation and lipolysis in Chinese dry sausage with different sodium chloride curing salt content. Food Sci. Hum. Well. 2020, 9, 328-337. [CrossRef]

15. Socaci, S.A.; Fărcaş, A.C.; Galanakis, C.M. Introduction in functional components for membrane separations. In Separation of Functional Molecules in Food by Membrane Technology; Academic Press: Cambridge, MA, USA, 2019; pp. 31-77.

16. Adegbeye, M.J.; Elghandour, M.M.; Faniyi, T.O.; Perez, N.R.; Barbabosa-Pilego, A.; Zaragoza-Bastida, A.; Salem, A.Z. Antimicrobial and antihelminthic impacts of black cumin, pawpaw and mustard seeds in livestock production and health. Agrofor. Syst. 2020, 94, 1255-1268. [CrossRef]

17. Tashla, T.; Puvača, N.; Pelić, D.L.; Prodanović, R.; Bošković, J.; Ivanišević, D.; Lević, J. Dietary medicinal plants enhance the chemical composition and quality of broiler chicken meat. J. Hell. Vet. Med. Soc. 2019, 70, 1823-1832. [CrossRef]

18. Breda, S.G.; Mathijs, K.; Sági-Kiss, V.; Kuhnle, G.G.; van der Weer, B.; Jones, R.R.; Sinha, R.; Ward, M.H.; de Kok, T.M. Impact of high drinking water nitrate levels on the endogenous formation of apparent N-nitroso compounds in combination with meat intake in healthy volunteers. Environ. Health 2019, 18, 1-12. 
19. Chauhan, P.; Das, A.K.; Nanda, P.K.; Kumbhar, V.; Yadav, J.P. Effect of Nigella sativa seed extract on lipid and protein oxidation in raw ground pork during refrigerated storage. Nutr. Food Sci. 2018, 48, 1. [CrossRef]

20. Mahgoub, S.A.M.; Osman, A.; Ramadan, M.F. Inhibitory effect of Nigella sativa oil against Listeria monocytogenes and Salmonella Enteritidis inoculated in minced beef meat. J. Food Meas. Charact. 2017, 11, 2043-2051. [CrossRef]

21. Zwolan, A.; Pietrzak, D.; Adamczak, L.; Chmiel, M.; Kalisz, S.; Wirkowska-Wojdyła, M.; Oszmiański, J. Effects of Nigella sativa L. seed extracts on lipid oxidation and color of chicken meatballs during refrigerated storage. LWT 2020, 130, 109718. [CrossRef]

22. Yimer, E.M.; Tuem, K.B.; Karim, A.; Ur-Rehman, N.; Anwar, F. Nigella sativa L. (black cumin): A promising natural remedy for wide range of illnesses. Evid. -Based Compl. Altern. Med. 2019. [CrossRef]

23. Topcagic, A.; Zeljkovic, S.C.; Karalija, E.; Galijasevic, S.; Sofic, E. Evaluation of phenolic profile, enzyme inhibitory and antimicrobial activities of Nigella sativa L. seed extracts. Bosn. J. Basic Med. Sci. 2017, 17, 286. [CrossRef] [PubMed]

24. Rani, R.; Kumar, S.; Yadav, S. Pumpkin and chia seed as dietary fibre source in meat products: A review. Pharma Inn. J. 2021, 10, 477-485.

25. Fernández-López, J.; Lucas-González, R.; Viuda-Martos, M.; Sayas-Barberá, E.; Navarro, C.; Haros, C.M.; Pérez-Álvarez, J.A. Chia (Salvia hispanica L.) products as ingredients for reformulating frankfurters: Effects on quality properties and shelf-life. Meat Sci. 2019, 156, 139-145. [CrossRef]

26. Fernández-López, J.; Viuda-Martos, M.; Pérez-Alvarez, J.A. Quinoa and chia products as ingredients for healthier processed meat products: Technological strategies for their application and effects on the final product. Curr. Opin. Food Sci. 2021, 40, 26-32. [CrossRef]

27. Kulczyński, B.; Kobus-Cisowska, J.; Taczanowski, M.; Kmiecik, D.; Gramza-Michałowska, A. The chemical composition and nutritional value of chia seeds-Current state of knowledge. Nutrients 2019, 11, 1242. [CrossRef]

28. Santillán-Álvarez, A.; Dublán-García, O.; López-Martínez, L.X.; Quintero-Salazar, B.; Gómez-Oliván, L.; Díaz-Bandera, D.; Hernández-Navarro, M.D. Effect of chia seed on physicochemical and sensory characteristics of common carp restructured as functional food. J. Food Sci. Eng. 2017, 7, 115-126. [CrossRef]

29. Zaki, E.F. Impact of adding chia seeds (Salvia hispanica) on the quality properties of camel burger "Camburger" during cold storage. Int. J. Curr. Microbiol. Appl. Sci. 2018, 7, 1356-1363. [CrossRef]

30. Commission Regulation (EU). No. 1129/2011 of 11 November 2011 amending Annex II to Regulation (EC) No. 1333/2008 of the European Parliament and of the Council by establishing a Union list of food additives. Off. J. Eur. Union 2011, 295, 1-177.

31. PN; ISO 1442: 2000. Meat and Meat Products-Determination of Moisture Content (Reference Method); Polish Committee for Standardization: Warsaw, Poland, 2000. (In Polish)

32. Pikul, J.; Leszczynski, D.E.; Kummerow, F.A. Evaluation of three modified TBA methods for measuring lipid oxidation in chicken meat. J. Agric. Food Chem. 1989, 37, 1309-1313. [CrossRef]

33. AMSA. Meat Color Measurements Guidelines; American Meat Science Association: Savoy, IL, USA, 2012.

34. Mokrzycki, W.S.; Tatol, M. Color difference $\Delta$ E-A survey. In Proceedings of the Machine Graphic \& Vision, Warsaw, Poland, 8 October 2012.

35. Hornsey, H.C. The colour of cooked cured pork. I.-Estimation of the Nitric oxide-Haem Pigments. J. Sci. Food Agric. 1959, 7, 534-540. [CrossRef]

36. ISO. ISO 11290-2:1998-Microbiology of Food and Animal Feeding Stuffs-Horizontal Method for the Detection and Enumeration of Listeria Monocytogenes-Part 2-Enumeration Method; ISO: Geneva, Switzerland, 1998.

37. Safaa, A.L.; Rewaa, A.A.M. Quality characteristics of chicken sausage formulated with chia seeds. Suez Canal Univ. J. Food Sci. 2019, 6, 87-96.

38. Pérez-Álvarez, J.Á.; García-Martín, J.; Roldán-Verdú, A.; Martínez-Mayoral, A.; de Vera, C.N.R.; Sayas-Barberá, E.; FernándezLópez, J. Application of chia seed coproduct in dry-cured sausages: Effect upon its physicochemical properties. Multidiscip. Digit. Publ. Inst. Proc. 2020, 70, 87.

39. Liu, Y.; Wan, Z.; Yohannes, K.W.; Yu, Q.; Yang, Z.; Li, H.; Liu, J.; Wang, J. Functional characteristics of Lactobacillus and yeast single starter cultures in the ripening process of dry fermented sausage. Front. Microbiol. 2021, 11, 3384. [CrossRef] [PubMed]

40. Agüero, N.D.L.; Frizzo, L.S.; Ouwehand, A.C.; Aleu, G.; Rosmini, M.R. Technological characterization of probiotic lactic acid bacteria as starter cultures for dry fermented sausages. Foods 2020, 9, 596. [CrossRef]

41. Domínguez, R.; Pateiro, M.; Gagaoua, M.; Barba, F.J.; Zhang, W.; Lorenzo, J.M. A comprehensive review on lipid oxidation in meat and meat products. Antioxidants 2019, 8, 429. [CrossRef] [PubMed]

42. Zhu, Y.; Yang, Q. Isolation of Antibacterial, Nitrosylmyoglobin Forming Lactic Acid Bacteria and Their Potential Use in Meat Processing. Front. Microbiol. 2020, 11, 1315. [CrossRef] [PubMed]

43. Deraz, S.F.; Khalil, A.A. A model system for conversion of metmyoglobin to bright red myoglobin derivatives in organic sausages using potential probiotic lactic acid bacteria. S. Asian J. Life Sci. 2018, 6, 22-35.

44. Karwowska, M.; Kononiuk, A. Nitrates/nitrites in food-Risk for nitrosative stress and benefits. Antioxidants $2020,9,241$. [CrossRef]

45. Cardinali, F.; Milanović, V.; Osimani, A.; Aquilanti, L.; Taccari, M.; Garofalo, C.; Haouet, M.N. Microbial dynamics of model Fabriano-like fermented sausages as affected by starter cultures, nitrates and nitrites. Int. J. Food Microbiol. 2018, $278,61-72$. [CrossRef] 
46. Łaszkiewicz, B.; Szymański, P.; Kołożyn-Krajewska, D. The effect of selected lactic acid bacterial strains on the technological and microbiological quality of mechanically separated poultry meat cured with a reduced amount of sodium nitrite. Poul. Sci. 2021, 100, 263-272. [CrossRef]

47. Duda-Chodak, A.; Tarko, T.; Satora, P.; Sroka, P. Interaction of dietary compounds, especially polyphenols, with the intestinal microbiota: A review. Eur. J. Nutr. 2015, 54, 325-341. [CrossRef] [PubMed]

48. Vieco-Saiz, N.; Belguesmia, Y.; Raspoet, R.; Auclair, E.; Gancel, F.; Kempf, I.; Drider, D. Benefits and inputs from lactic acid bacteria and their bacteriocins as alternatives to antibiotic growth promoters during food-animal production. Front. Microbiol. 2019, 10, 57. [CrossRef] [PubMed]

49. Meloni, D. High-hydrostatic-pressure (HHP) processing technology as a novel control method for Listeria monocytogenes occurrence in Mediterranean-style dry-fermented sausages. Foods 2019, 8, 672. [CrossRef] [PubMed]

50. Akan, S.; Ocak, Ö.Ö. Evaluation of storage time and grape seed extract addition on biogenic amines content of tarhana: A cereal-based fermented food. LWT 2019, 111, 861-868. [CrossRef]

51. Doeun, D.; Davaatseren, M.; Chung, M.S. Biogenic amines in foods. Food Sci. Biotechnol. 2017, 26, 1463-1474. [CrossRef]

52. Świder, O.; Roszko, M.Ł.; Wójcicki, M.; Szymczyk, K. Biogenic amines and free amino acids in traditional fermented vegetablesDietary risk evaluation. J. Agric. Food Chem. 2019, 68, 856-868. [CrossRef] [PubMed]

53. Latorre-Moratalla, M.; Bover-Cid, S.; Veciana-Nogués, M.T.; Vidal-Carou, M.C. Control of biogenic amines in fermented sausages: Role of starter cultures. Front. Microbiol. 2012, 3, 169. [CrossRef]

54. Kononiuk, A.D.; Karwowska, M. Comparison of selected parameters related to food safety of fallow deer and beef uncured fermented sausages with freeze-dried acid whey addition. Meat Sci. 2020, 161, 108015. [CrossRef]

55. Barbieri, F.; Montanari, C.; Gardini, F.; Tabanelli, G. Biogenic amine production by lactic acid bacteria: A review. Foods 2019, 8, 17. [CrossRef]

56. Del Rio, B.; Redruello, B.; Linares, D.M.; Ladero, V.; Ruas-Madiedo, P.; Fernandez, M.; Alvarez, M.A. The biogenic amines putrescine and cadaverine show in vitro cytotoxicity at concentrations that can be found in foods. Sci. Rep. 2019, 9, 1-7. [CrossRef]

57. Galgano, F.; Caruso, M.; Condelli, N.; Favati, F. Focused review: Agmatine in fermented foods. Front. Microbiol. $2012,3,199$. [CrossRef] [PubMed]

58. Barua, S.; Kim, J.Y.; Kim, J.Y.; Kim, J.H.; Lee, J.E. Therapeutic effect of agmatine on neurological disease: Focus on ion channels and receptors. Neurochem. Res. 2019, 44, 735-750. [CrossRef] [PubMed]

59. Kononiuk, A.D.; Karwowska, M. Influence of freeze-dried acid whey addition on biogenic amines formation in a beef and deer dry fermented sausages without added nitrite. Asian-Austral. J. Anim. Sci. 2020, 33, 332. [CrossRef] [PubMed]

60. Özogul, Y.; Özogul, F. Chapter 1: Biogenic amines formation, toxicity, regulations in food. In Biogenic Amines in Food. Analysis, Occurrence and Toxicity; Royal Society of Chemistry: Cambridge, UK, 2019; pp. 1-17.

61. Grootveld, M.; Percival, B.C.; Zhang, J. Extensive chemometric investigations of distinctive patterns and levels of biogenic amines in fermented foods: Human health implications. Foods 2020, 9, 1807. [CrossRef]

62. EFSA. EFSA Scientific opinion on risk based control of biogenic amine formation in fermented foods. EFSA. Panel Biol. Hazards (BIOHAZ) EFSA J. 2011, 9, 2393. 